\title{
Collagen Fibrillar Networks as Skeletal Frameworks: A Demonstration by Cell-Maceration/Scanning Electron Microscope Method
}

\author{
Osamu Ohtani ${ }^{1}$, Tatsuo Ushiki ${ }^{2}$, Takehito Taguchi ${ }^{1}$ and Akio KikUta ${ }^{1}$ \\ Departments of Anatomy, Okayama University School of Medicine ${ }^{1}$, Okayama, and Iwate Medical College School of Medicine ${ }^{2}$, \\ Morioka, Japan \\ Received December 30, 1987
}

\begin{abstract}
Summary. A cell-maceration/scanning electron microscope (SEM) method was employed to demonstrate the arrangement of the collagen fibrillar network of various tissues. Immersion of fixed tissues in $\mathrm{NaOH}\left(25^{\circ} \mathrm{C}\right)$ for $3-$ 7 days, followed by rinsing in distilled water successfully removed the cellular elements, exposing collagen fibrils which were identified as such by transmission electron microscopy in their natural locations. SEM observations of the preparations are able to demonstrate the three-dimensional architecture of collagen fibrils much more precisely than other methods, including the silver impregnation method.

Collagen fibrils, forming sheaths for housing individual cardiac myocytes, fused together, thus ensuring an equal stretch of contiguous myocytes and preventing the slippage of adjacent cells. Individual skeletal muscle fibers and nerve fibers were ensheathed by the meshwork of collagen fibrils running in two opposite helices. Such structures seem to play an important role in resisting the stretching impetus. At the epithelial-connective tissue junction of the tongue and fingertip skin, interwoven collagen fibrils formed numerous microridges which probably provide a broad anchorage for the epithelium. In the intestinal mucosa, the collagen fibrillar network immediately below the basal laminae of the villous epithelium possessed heterogeneous pores. As the collagen fibrillar network shows morphological features specific to individual organs and tissues, it is suggested that such formations not only constitute the skeletal framework but also provide those cells which are housed there with a microenvironment suitable for their activities.
\end{abstract}

The connective tissues constitute the skeletal frameworks of the organs. The organization of the connective tissue framework of each organ undoubtedly reflects the function of the organ.

In the first half of this century light microscopy of silver-impregnated preparations was the principal technique for the study of the connective tissues (e.g., HolmGREN, 1907; Plenk, 1927; NAGEL, 1934, 1935; ClarA, 1936), and the fine three-dimensional organization of the connective tissues could not be properly visualized. During the last decade, scanning electron microscopy (SEM) has become widely employed to obviate this disadvantage, but demonstration of the structure of connective tissue fibers under the SEM has been disturbed by the presence of hampering cellular elements.

Recently one of the authors (OHTANI, 1987) introduced a cell-maceration method with a low temperature $\mathrm{NaOH}$ solution for SEM observations of connective tissue fiber arrangements. Other authors have actually attempted to remove cellular elements to expose the connective tissues, using acetic acid (HORSTMANN, 1952, 1954, 1957), trypsin (SCHENK and WERSALL, 1975), EDTA (KLEIN-SZANTO and SchroEdER, 1977), prolonged fixation in $\mathrm{OsO}_{4}$ followed by ultrasonication (HIGHISON and LOW, 1982), maceration in boric acid plus ultrasonication (LOW and MCCLUGAGE, 1984), washing in a jet of Ringer's solution (MIYOSHI and SHINGU, 1984), or with low temperature $\mathrm{HCl}$ (KOBAYASHI, MiYatA and IINO, 1987). Our experiments, however, have revealed that treatment with $\mathrm{NaOH}$ at room temperature is able to remove cellular elements much more effectively and consistently, and thus more clearly expose the connective tissue fibers than any other methods so far reported.

The present study shows the wide applicability of the "cell-maceration/SEM method" to the study of connective tissue fibrillar arrangement of various tissues, and demonstrates collagen fibrillar networks as skeletal frameworks of the body. The significance of the specific pattern of the networks is also discussed. 


\section{MATERIALS AND METHODS}

The materials used were the tongue of an adult mongrel dog (10 kg body weight), and the small intestine of an adult rabbit ( $3.5 \mathrm{~kg}$ body weight). The human tissues used were cardiac muscle and fingertip skin obtained in the autopsy of two Japanese male individuals who died of lung cancer at 74 years of age and of acute heart failure at 57 years of age, respectively. Routine light microscopy of hematoxylin-eosin stained tissues revealed no significant pathological alterations in the materials.

The materials were fixed in $2.5 \%$ glutaraldehyde or $4 \%$ paraformaldehyde in a $0.1 \mathrm{M}$ phosphate buffer solution ( $\mathrm{pH}$ 7.3) by either perfusion or immersion, cut into small pieces measuring $2 \times 3 \times 5-5 \times 5 \times 5 \mathrm{~mm}$ and then put into $2.5 \%$ glutaraldehyde for more than a day. The pieces were immersed in a $10 \%$ aqueous solution of $\mathrm{NaOH}$ for 3-7 days at room temperature (about $25^{\circ} \mathrm{C}$ ), and then rinsed in distilled water for a day or two, or until the pieces became transparent. They were then processed by the conductive staining method by MURAKAMI (1974): they were put in a $1 \%$ aqueous solution of tannic acid for 2-3 h, rinsed in distilled water for several hours, and postfixed in a $1 \%$ aqueous solution of $\mathrm{OsO}_{4}$ for 1-2 h. The specimens were dehydrated in a series of graded concentrations of ethanol, freeze-cracked with a razor blade in liquid nitrogen, and critical point-dried using liquid $\mathrm{CO}_{2}$. The dried specimens were mounted on metal stubs with a double sticky tape, coated with gold, and observed under the SEM (JSM-U3, JEOL, or HSM$2 \mathrm{~B}$, Hitachi) with an accelerating voltage of $10-15 \mathrm{kV}$. Stereo pairs of SEM images were frequently taken with a tilt separation of 6-7 degrees to examine the spatial relationships of the structures. Some tissue pieces at the $100 \%$ ethanol step were processed for transmission electron microscopy (TEM) to examine how collagen fibrils were preserved after maceration.

\section{RESULTS}

\section{Effects of the treatment with $\mathrm{NaOH}$}

Maceration of the tissues with a $\mathrm{NaOH}$ solution (about $25^{\circ} \mathrm{C}$ ), followed by extensive washing in dis- tilled water effectively and consistently removed the cellular elements and their basal laminae, exposing the connective tissue fibers.

TEM observations showed that the structures exposed with $\mathrm{NaOH}$ were collagen fibrils in well preserved natural locations (Fig. 1). The diameter of the collagen fibrils ranged from 20 to $100 \mathrm{~nm}$. Fine granules of electron dense materials were observed adhering to the surfaces of the collagen fibrils (Fig. 1). SEM observations showed that collagen fibers were bundles consisting of numerous collagen fibrils. From the bundles of collagen fibrils, thinner bundles and fibrils branched off and formed networks surrounding the cellular elements.

The optimal duration of the $\mathrm{NaOH}$ treatment was 3-7 days depending on the tissue type and size. With shorter treatment, the cellular elements, especially cell nuclei tended to persist.

\section{Collagen fibrillar network of the cardiac muscle}

The cardiac muscle of the human left ventricle macerated by the present method showed numerous labyrinthine tubes (4-7 $\mu \mathrm{m}$ in diameter) for housing individual cardiac myocytes. Each tube consisted of a network of collagen fibrils taking winding courses, though running more or less circularly or spirally around the space for the myocyte (Fig. 2). Such collagen fibrils of the sheath came off from the bundles of collagen fibrils that wound longitudinally in the outer parts or between the sheaths for the myocytes. The collagen fibrillar sheaths of neighboring myocytes were interconnected by numerous collagen fibrils (Fig. 2). At the site where the myocyte bifurcated, there was a collagen fibrillar septum with a free edge. The collagen fibrillar sheath for the myocyte occasionally possessed oval fenestrae through which myocytes were presumed to form lateral connections in the natural state. Besides these collagen sheaths, there were narrow collagen fibrillar sheaths for housing blood vessels in the endomysium.

\section{Endomysial collagen fibrillar network of the dog lingual muscle}

The space for accommodating the skeletal muscular fiber in the dog tongue was demarcated by a cylindrical sheath (15-25 $\mu \mathrm{m}$ in diameter) arranged in paral-

Fig. 1. TEM views of dog lingual muscle treated with the cell-maceration method. The collagen fibrils demarcating the spaces $(M)$ for the muscle fibers are well preserved, while no cellular elements remain. Figure $\mathbf{1 b}$ is a closer view of a part of Figure 1a showing fine granules of electron dense materials deposited on the surface of the collagen fibrils. a: $\times 2,400, b: \times 30,000$ 


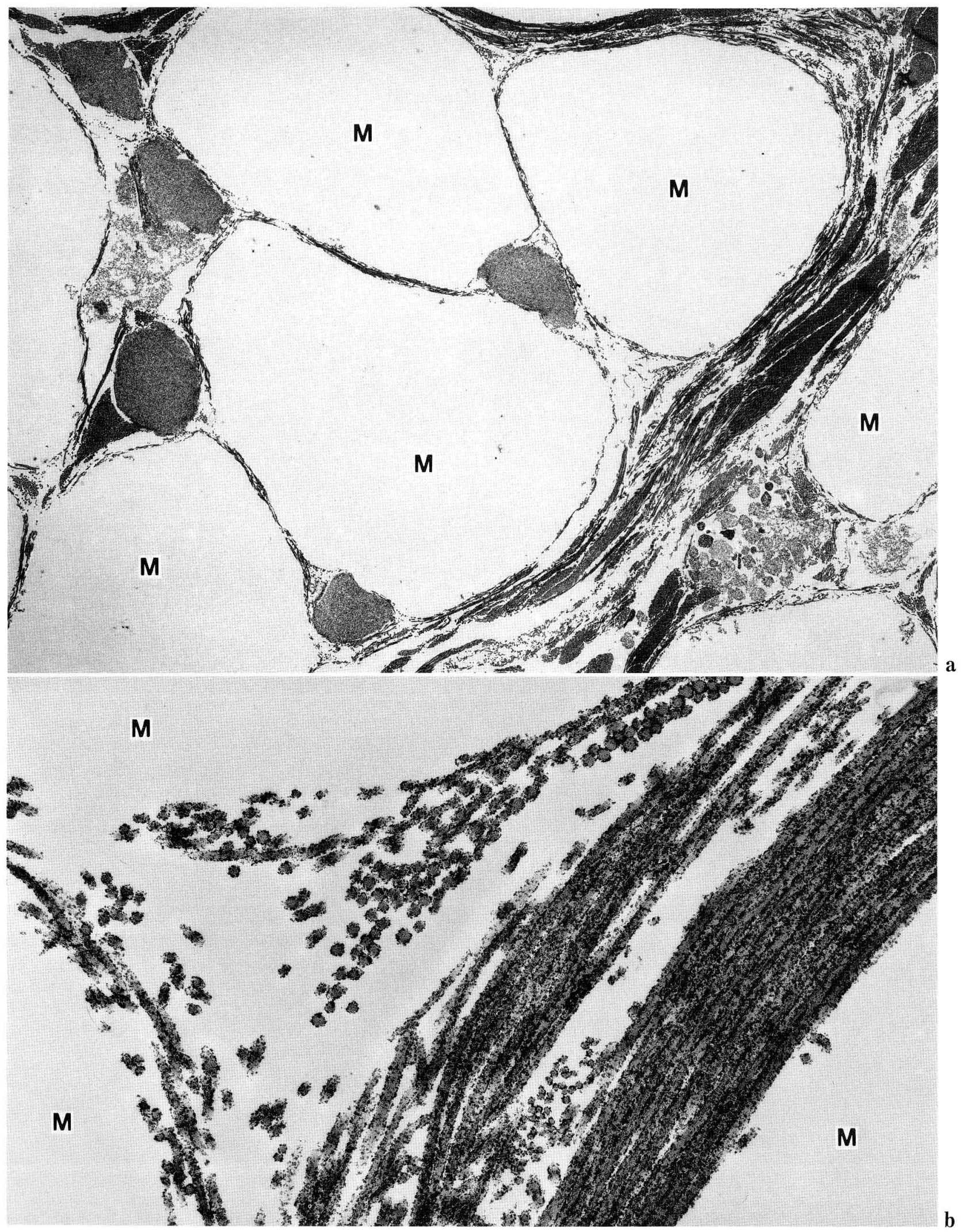

Fig. 1. Legend on the opposite page. 


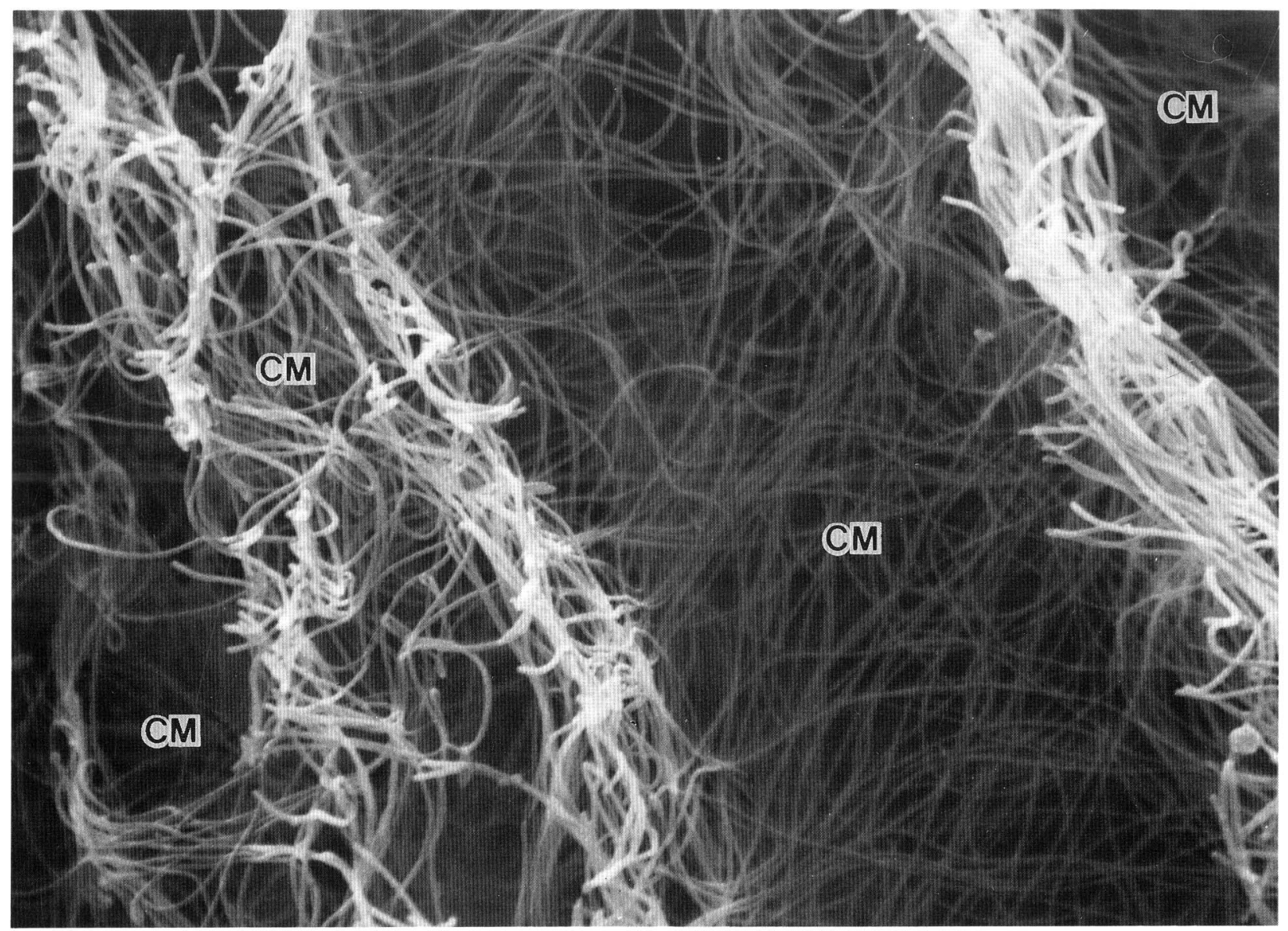

Fig. 2. A SEM view of the collagen fibrillar network of human cardiac muscle (left ventricle) treated with the cell-maceration method. The sheaths for accommodating cardiac myocytes $(C M)$ consist of circumferentially or spirally arranged collagen fibrils. Note that the fibrils of the sheath for a myocyte extend into that for another, adjacent myocyte. $\times 13,500$

lel (Fig. 3). This endomysial collagen sheath was separated into two layers. The outer layer consisted of bundles of collagen fibrils which wound in longitudinal courses and gave off numerous smaller bundles and fibrils. These, in turn, took wavy and rather transverse courses, repeatedly anastomosing and branching to form the inner layer of the sheath (Fig. 3). Most of the collagen fibrils of the inner layer were arranged in two opposing spirals. There seemed to be few collagen fibrils intervening between adjacent endomysial sheaths. Between the endomysia there also existed thick bundles of collagen fibrils winding in longitudinal courses (Fig. 3).

\section{Collagen fibrillar sheaths of dog lingual nerves}

Treatment of the dog lingual nerves with the present method revealed the endoneurial collagen fibrillar sheath (2-5 $\mu \mathrm{m}$ in diameter) for accommodating individual nerve fibers (Figs. 4, 5). The endoneurial sheath consisted of two distinct layers of collagen fibrils. The inner layer was composed of collagen fibrils that were arranged in two opposing spirals, thus forming an extremely delicate meshwork surrounding individual nerve fibers. The outer layer, on the other hand, consisted of bundles (several micrometers in diameter) of collagen fibrils running in a longitudinal direction along the axis of the nerve fibers. The bundles of collagen fibrils of the outer layer often gave off collagen fibrils into the inner layer. The thicker bundles of collagen fibrils of the outer layer tended to locate in regions where three or more sheaths met (Fig. 5). The endoneurial collagen fibrillar sheaths were packed together by the perineural and epineurial collagen fibrillar sheets (Fig. 4). 


\section{Collagen fibrillar network at the epidermo-dermal junction of fingertip skin}

Treatment of the palmar skin of the human fingertips with the present method exposed a collagen fibrillar sheet at the dermal surface (Figs. 5-7). There were numbers of connective tissue papillae between the dermal grooves. These papillae, varying in size and shape, projected towards the epidermis, and arrayed themselves in double rows along the dactylograms (Fig. 5). Most of the connective tissue papillae were finger-like in shape, but some appeared in tongue-like protrusions of irregular shapes. In addition, several small finger-like projections were frequently observed on top of the individual papillae (Fig. 5). The shapes of the connective tissue papillae also showed individual differences.

At higher magnification, the dermal surface of the papillae showed numerous microridges made up of interwoven collagen fibrils (Figs. 6, 7). Near the tip of the papilla, the ridges interconnected with one another to form ring-like folds, while at the shaft of the papilla the ridges were oriented parallel to the long axis of the papilla (Fig. 6). However, at the very top of the papilla, the ridges became broader and frequently terminated as sinuous folds. At the base of the papillae the microridges were arranged in a honeycomb pattern similar to those seen around the top of the papilla. At the dermal surface of the secondary dermal grooves the collagen fibrils, running in various directions, formed many round or oval shallow depressions on the dermal surface (Fig. 7a), while that of the primary dermal groove consisted of a rather smooth sheet of interwoven collagen fibrils (Fig. 7b).

The primary dermal grooves possessed regularly scattered tunnel-like structures $(45-60 \mu \mathrm{m}$ in diameter) for accommodating eccrine sweat glands at intervals of $120-260 \mu \mathrm{m}$ (Fig. 5). Small fenestrae (3-4 $\mu \mathrm{m}$ in diameter) were also observed in the grooves (Fig. 7).

\section{Collagen fibrillar network of connective tissue papillae in the tongue}

The dorsum of the tongue treated with the present method exposed the connective tissue sheet of the dermis (Fig. 8). The sheet, consisting of interwoven collagen fibrils, displayed a reticular pattern of small ridges studded with flower shaped projections, i.e., the connective tissue papillae underlying the lingual papillae. The ridges interconnected with each other and formed numerous depressions of various sizes and shapes (Fig. 8). The connective tissue papilla also showed numerous parallel microridges on its surface

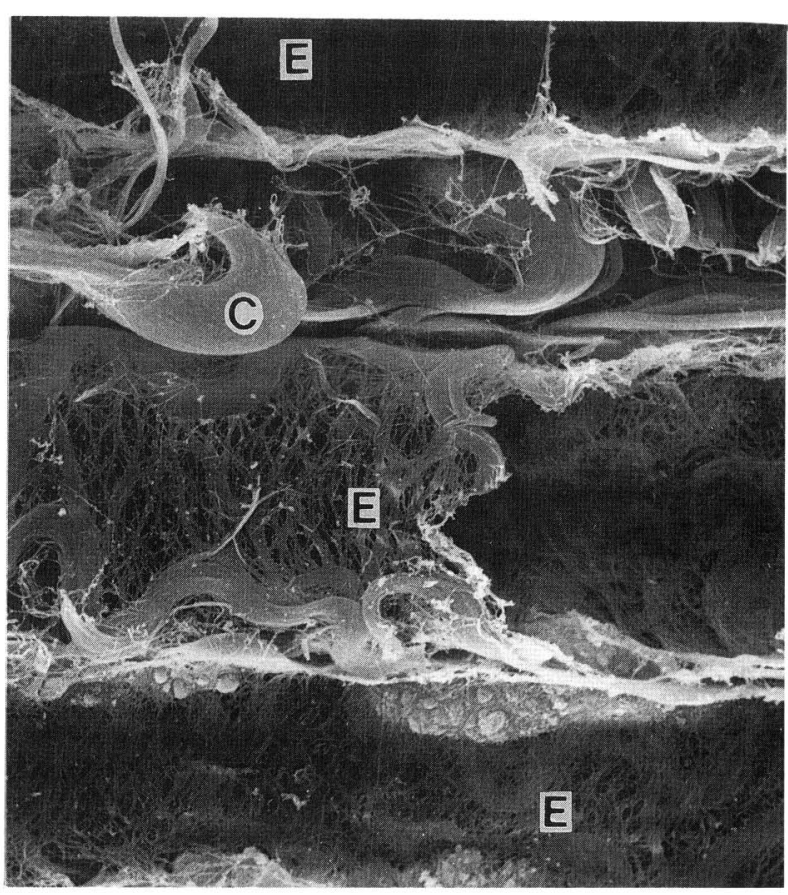

Fig. 3. A SEM view of the endomysial collagen fibrillar network of dog lingual muscle treated with the cellmaceration method. Endomysial connective tissue fibers $(E)$ form cylindrical sheaths which consist of two layers: the inner layer of helically arranged collagen fibrils, and the outer layer of longitudinal bundles of collagen fibrils. Between the endomysial sheaths are thicker bundles of collagen fibrils (or collagen fibers) $(C)$ that take winding courses. $\times 1,300$

similar to those seen on the dermal surface in the human fingertip skin (Fig. 8b). The filiform papillae were arranged regularly in distinct rows, while the fungiform papillae were scattered singly among the filiform papillae (Fig. 8a).

The connective tissue papillae of the filiform papillae showed a distinct polarity in shape with regard to their orientation in the tongue. At the center of the filiform papillae was an elliptical groove, measuring $40 \mu \mathrm{m}$ in transverse diameter and $120 \mu \mathrm{m}$ in longitudinal diameter (Fig. 8b). Surrounding the groove were 8-12 petal-like projections of connective tissue. The petal located at the anterior pole of the groove was the largest, measuring about $90 \mu \mathrm{m}$ in length (anteroposteriorly) and $40 \mu \mathrm{m}$ in width (transversely); posteriorly the papillae became gradually smaller in size. The petal-like projection was lacking at the posterior pole of the groove (Fig. 8). The connective tissue papillae of the fungiform papillae, on the other hand, were solid, lumpy projections (approximately $150 \mu \mathrm{m}$ diameter) with several small swellings on their tops 

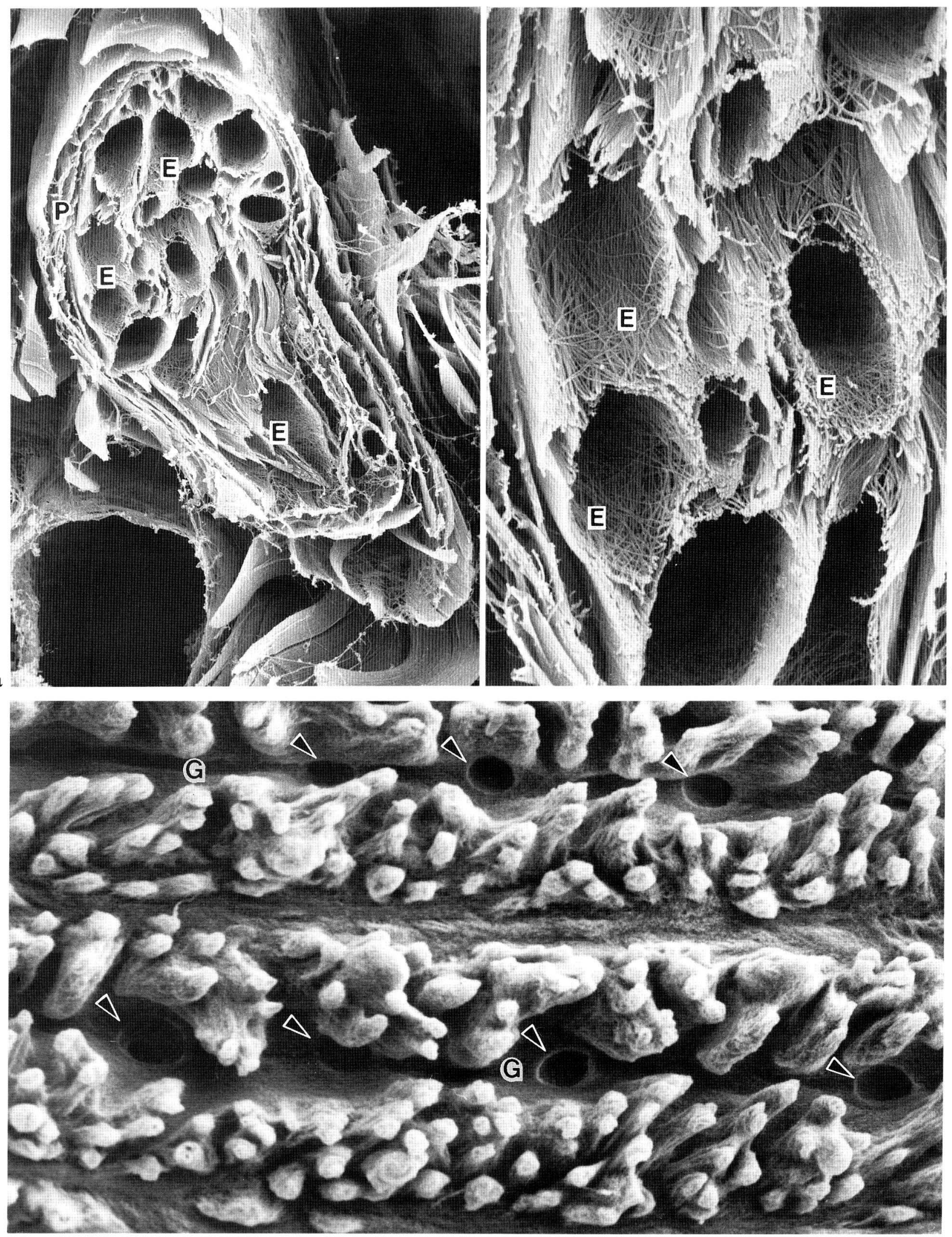

Fig. 4 and 5. Legends on the opposite page. 
(Fig. 8a, arrowhead). In the core of the connective tissue papillae of both filiform and fungiform papillae, there were switchback-channels for accommodating capillary loops.

\section{Collagen fibrillar network of the small intestine}

The $\mathrm{NaOH}$ treatment of the intestine exposed the collagen sheets underlying the epithelium of the villi and crypts (Fig. 9). These collagen sheets were composed of interwoven collagen fibrils. The collagen fibrillar network of the villi showed many fenestrae of various sizes $(0.5-4 \mu \mathrm{m}$ in diameter) and shapes (Fig. 9c). The collagen fibrils ran circularly along the rims of the fenestrae at their periphery (Fig. 9c). The fibrils around larger fenestrae were denser in arrangement than those around the smaller ones (Fig. 9c). The smaller fenestrae were sometimes covered with several collagen fibrils. The collagen fibrillar network surrounding the crypts did not possess any fenestrae as seen in the villi (Fig. 9b).

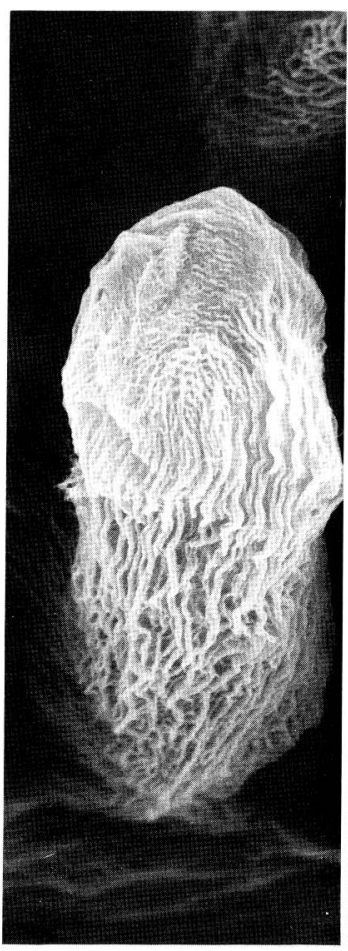

a
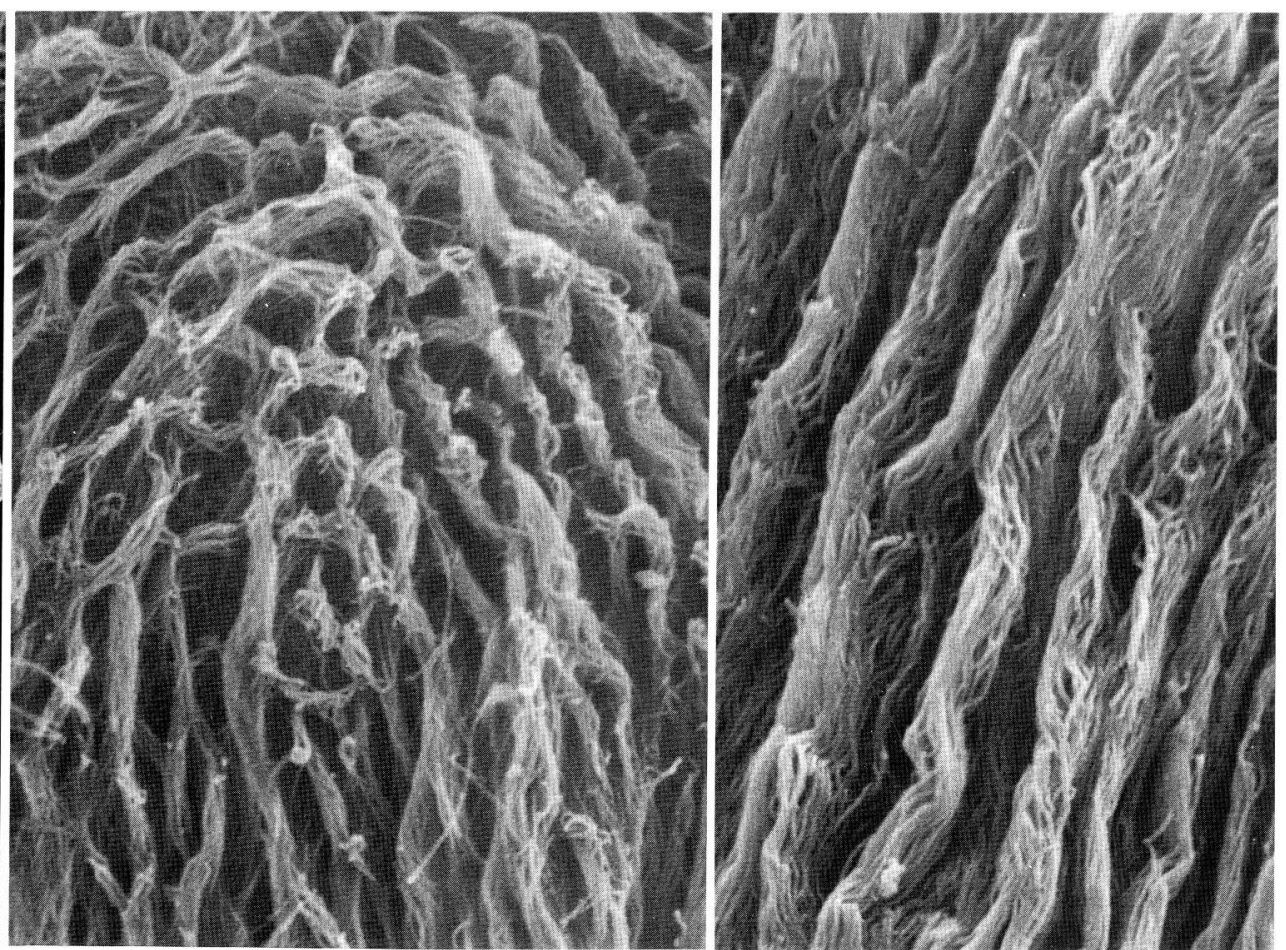

b

Fig. 6. SEM views of a connective tissue papilla of human fingertip skin treated with the cell-maceration method. The collagen fibrillar network of the connective tissue papilla shows numerous microridges. Near the tip of the papilla, the microridges interconnect with each other to form a honeycomb-like structure (b), while at the shaft of the papilla the microridges are oriented parallel to its long axis (c). a: $\times 900, b: \times 8,000, c: \times 8,000$

Fig. 4. SEM views of the collagen fibrillar network of dog lingual nerves treated with the cell-maceration method. a. The endoneurial collagen sheaths $(E)$ for housing individual nerve fibers are packed together by a perineurial collagen sheath $(P) . \times 1,500$. b. A closer view of a part of Figure 4a showing endoneurial collagen fibrillar networks $(E)$ of the inner layer. Between the collagen fibrillar sheaths are condensations of thicker bundles of collagen fibrils that run longitudinally along the sheaths. Note that the collagen fibrils of the inner layer of the endoneurium are arranged in two opposing spirals. $\times 5,000$

Fig. 5. A SEM view of human fingertip skin treated with the cell-maceration method shows the collagen fibrillar network at the epidermo-dermal junction. Numerous connective tissue papillae project towards the epidermis and line up in double rows. Between the double rows of the connective tissue papillae, i.e., the primary dermal groove $(G)$, are round pits (arrowheads) for sweat glands. $\times 180$ 

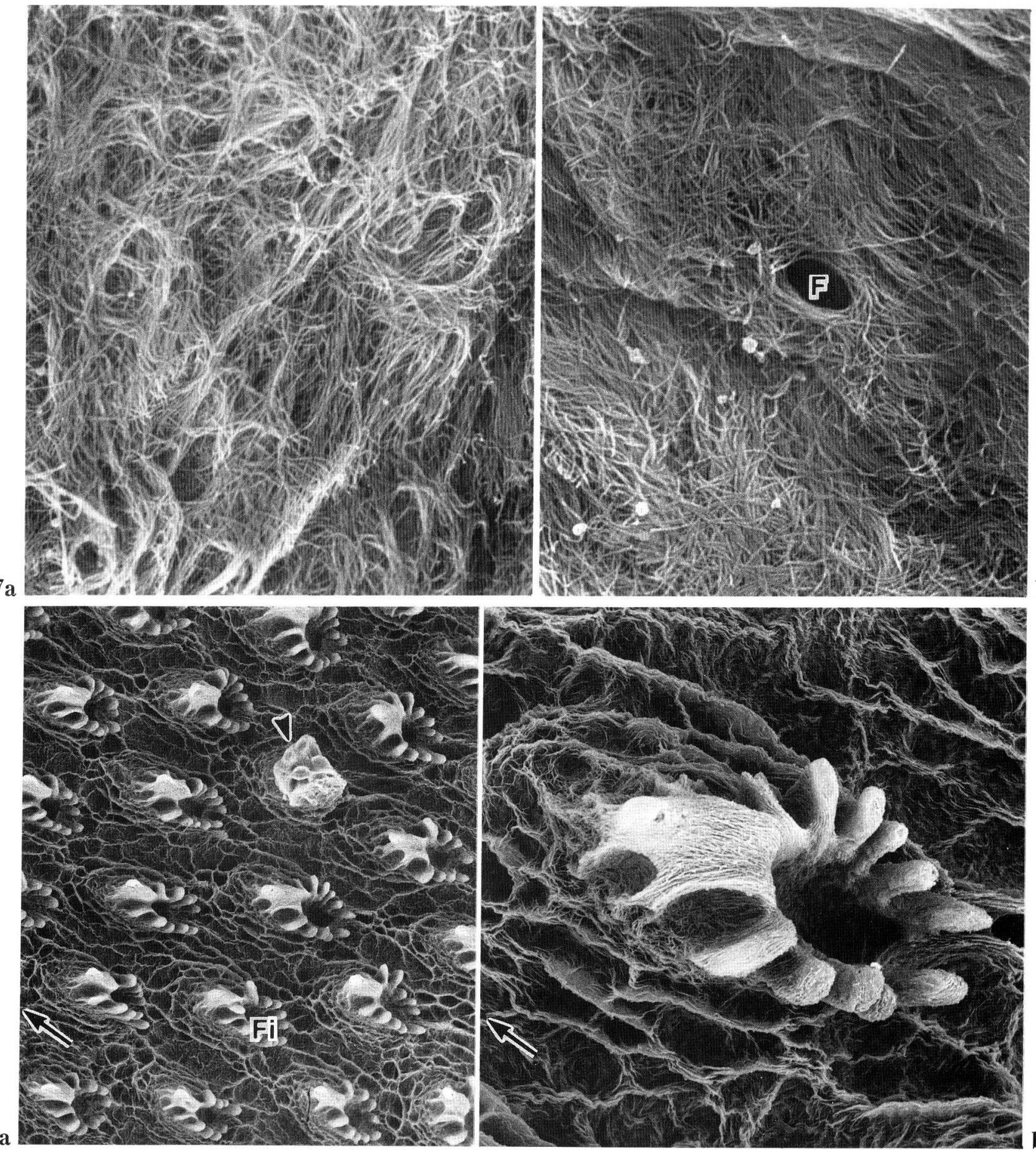

Fig. 7. SEM views of the collagen fibrillar network of primary dermal grooves. Near the base of the connective tissue papillae are many shallow round depressions surrounded by collagen fibrils (a), while the collagen fibrillar network of the bottom of the groove shows a rather smooth surface with occasional fenestrae $(F)(\mathbf{b}) . \times 8,000$

Fig. 8. SEM views of the dorsum of the dog tongue treated with the cell-maceration method. The arrows indicate the anterior direction of the tongue. a. The collagen fibrillar network of the surface of the dermis shows numerous microridges and the connective tissue papillae of the filiform papillae (Fi) lined up in distinct rows. Note a connective tissue papilla of the fungiform papilla (arrowhead). $\times 75$. b. A closer view of another connective tissue papilla of the filiform papilla. $\times 300$ 


\section{DISCUSSION}

\section{Methodology}

The present study has clearly shown that the cellmaceration/SEM method previously described by one of us (OHTANi, 1987) is applicable to the demonstration of collagen fibrillar networks of various organs and tissues.

Treatment of various organs and tissues with a $\mathrm{NaOH}$ aqueous solution (about $25^{\circ} \mathrm{C}$ ) eliminates cellular elements and exposes the connective tissue fibers much more effectively and consistently than any other method so far described. Our TEM observations have shown that the structures extracted with the cell-maceration method are really collagen fibrils, which are well preserved in their natural locations.
Light microscopy of silver-impregnated preparations can only show bundles of collagen fibrils, but not individual collagen fibrils, since the diameter of the collagen fibril, ranging from $20-100 \mathrm{~nm}$, is much smaller than the resolving power of the light microscope. The present method, on the other hand, can clearly demonstrate individual collagen fibrils, regardless of whether they form bundles or course solitarily.

Our cell-maceration/SEM method is, therefore, highly useful for observation of the arrangements manifested by collagen fibrils in various tissues and organs. It is expected to facilitate studying alterations in fibrillar arrangements in pathological states.

Our TEM observations of the $\mathrm{NaOH}$-treated tissues show that fine granules of electron dense materials are deposited on the surface of the collagen fibrils. The granules may be precipitates made by tannic acid.

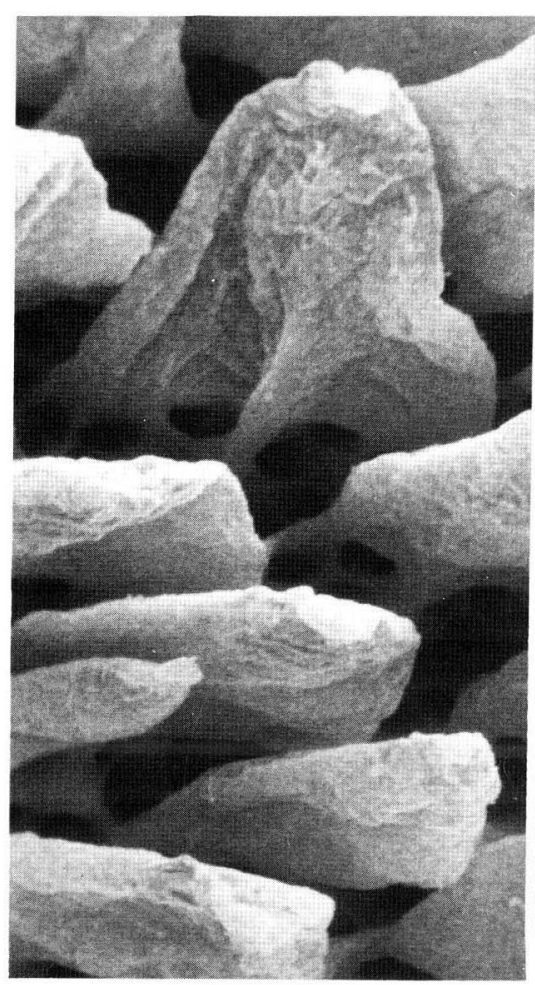

$\mathbf{a}$
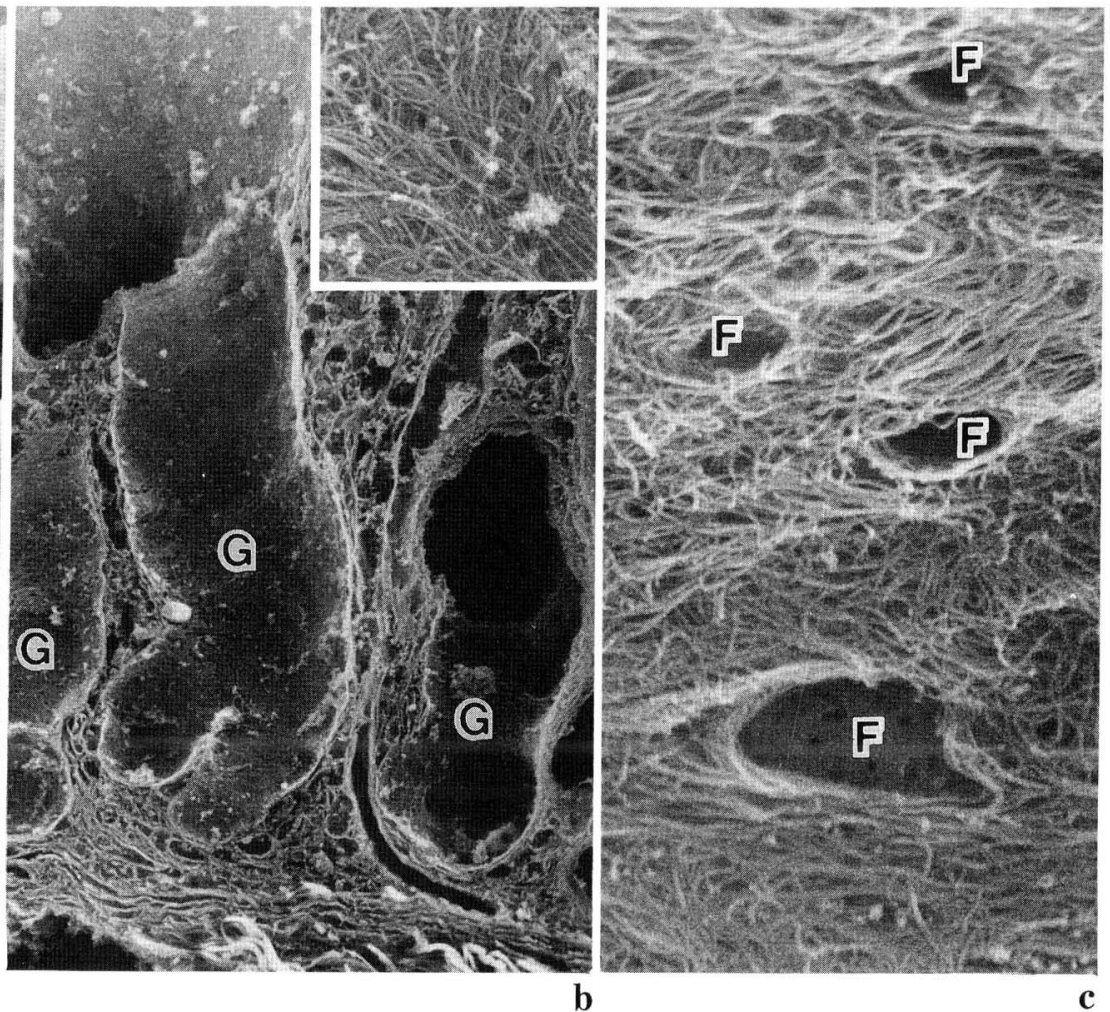

Fig. 9. SEM views of rabbit small intestine treated with the cell-maceration method. a. At a low magnification, the external appearance of the villous connective tissue fibers resembles that of non-treated villi. Between the bases of the villous connective tissue fibers are openings of the holes for accommodating the intestinal glands. $\times 180$. b. The spaces for the intestinal glands $(G)$ are surrounded by the felt-like collagen fibrillar network (Inset). $\times 500$ (Inset: $\times 5,000$ ). c. A closer view of part of Figure 9a showing the interwoven collagen fibrillar network underlying the basal lamina of the villous epithelium. The network possesses fenestrae $(F)$ of various sizes and shapes. Note that the collagen fibrils around the large fenestra (which is seen at the bottom of the picture) are denser than those around the smaller fenestrae. $\times 8,000$ 
In order to obtain quality SEM images of the connective tissue fibers, extensive washing of the $\mathrm{NaOH}$ treated tissues in distilled water is imperative. Tissues which contain abundant fat should be dehydrated in ethanol and immersed in acetone to remove the fat, prior to $\mathrm{NaOH}$ treatment.

\section{Collagen fibrillar networks as skeletal frameworks}

The present study has clearly demonstrated the threedimensional architecture of collagen fibrils, especially that of collagen fibrillar networks abutting on the cellular elements of various organs and tissues. These had previously been visualized much less clearly by light microscopy of silver impregnated preparations and conventional SEM and TEM. Since the collagen fibrillar network presented here shows the pattern specific to individual organs and tissues, the network undoubtedly constitutes the skeletal framework, and also contributes toward maintaining a microenvironment suitable for the activities of the cells associated with the fibrillar network.

\section{Collagen microfibrillar network of the cardiac myocyte}

The present study has clearly demonstrated the collagen fibrillar sheath for accommodating individual myocytes or groups of myocytes. Several investigators have reported so-called intercellular collagen struts which are defined as bundles of collagen fibrils often attached near the Z-band level (CAULFIELD and Borg, 1979; PERLMAN et al., 1982; RoBInson, COHENGOULD and FACTOR, 1983). Such structures were, however, not recognizable in the present study. Instead, findings were that the circumferentially oriented collagen fibrils surrounding a myocyte extend to surround adjacent myocytes. Such collagen fibrils occurred not only at the Z-band level but also along the entire level of the myocyte. This organization of collagen fibrils may ensure the equal stretch of contiguous myocytes and prevent slippage of adjacent cells.

The oval or round fenestrae of the collagen fibrillar sheaths for housing the myocytes seem to indicate the sites where neighboring myocytes connect side to side along the lateral surface.

As reported by DOLBER and SPACH (1987), the architecture of collagenous structures may vary not only with age, species, and pathological state, but also within regions, a possibility we are now investigating by our cell-maceration/SEM method.

\section{Collagen fibrillar network of the endomysium of the skeletal muscle}

The present study has clearly demonstrated that collagen fibrillar network of the endomysium consists of two layers: the inner layer made up of collagen fibrils running in two opposing helices along the muscle fibers, and the outer layer of bundles of collagen fibrils winding in longitudinal courses.

It has been suggested that the breaking force of the muscle lies in the fine network of collagen fibrils of the sarcolemma, and not in the epimysium or perimysium (CASELLA, 1950). The resistance to stretching is reported to be unaltered in rat muscles at rest when the epimysium is circumferentially sectioned (STOLOV and WeILEPP, 1966). As assumed by PETERSEN (1922) and clearly demonstrated in the present study, the endomysial collagen fibrils of the inner layer are arranged in two opposing helices. SchmaLBRUCH (1974) demonstrated, in his TEM study of replicas of the surface of frog muscle fibers, that the helically arranged collagen fibrils surrounding muscle fibers are slack at equilibrium length and their orientation changes during contraction. In this connection, it seems natural that the inner fine collagen fibrillar sheath of the endomysium plays an important role in resisting stretching forces along the muscle fibers (SCHMALBRUCH, 1985).

The longitudinally oriented bundles of collagen fibrils that exist between the endomysial collagen fibrillar sheaths also seem to be involved in resisting the excessive stretching forces along muscle fibers.

Noteworthy is that the individual endomysial collagen fibrillar sheaths of the skeletal muscle are not so tightly connected with adjacent ones as are the collagen fibrillar sheaths investing the cardiac myocytes. This indicates that individual muscle fibers in the skeletal muscle are, to some extent, independent fibers, and thus each of them is allowed a certain degree of freedom of motion (FAWCETT, 1986). On this point, the collagen fibrillar sheath for housing the skeletal muscle fiber differs greatly from that for the cardiac myocyte: the latter is so organized that the adjacent myocytes move synchronously with little independence.

\section{Collagen fibrillar network of the endoneurium}

PlENK $(1927,1934)$ was first to recognize two layers in the endoneurial sheath investing individual myelinated fibers in human peripheral nerves by light microscopy of silver-impregnated preparations: the outer layer consisting of longitudinally oriented col- 
lagen fibers, the inner layer of a delicate meshwork of fine argyrophilic fibers. A recent SEM observations of mouse sciatic nerves by USHIKI and IDE (1986) demonstrated three-dimensional views of the endoneurial collagen sheaths and confirmed what PLENK $(1927,1934)$ described. In addition to these reports, the present study has clearly demonstrated that collagen fibrils of the inner layer are arranged in two opposing spirals, and those of the outer layer form bundles running longitudinally.

As reported in early light microscopic studies (LAIDLAW, 1930; NAGEOTTE, 1932) and in a recent SEM study (USHIKI and IDE, 1986), there is a continuity between the outer and inner layers of the endoneurial collagen sheath.

The collagen fibrillar sheath of the endoneurium may play an important role in resisting the stretching forces along the nerve fibers (USHIKI and IDE, 1986). The inner collagen fibrillar meshwork may also contribute toward maintaining a specific microenvironment for Schwann cells ensheathing nerve fibers.

\section{Collagen fibrillar network at the epithelial- connective tissue junction}

Recent SEM studies of human thick skin (HULL and WARFEL, 1983; Misumi and AKIYOSHI, 1984; KAWABE, MACCALlUM and LiLlie, 1985) and of the tongue (KARRING, 1973; KLEIN-SZANTO and SCHROEDER, 1977; Kobayashi, Miyata and Ino, 1987) have demonstrated a complex folded pattern on the dermal surface of the epidermal-dermal junction. In addition to confirming such previous findings, we have clearly demonstrated the arrangement of the collagen fibrils of the dermal surface of the human fingertip skin and the dog tongue.

The present study found that numerous microridges consisting of a network of interwoven collagen fibrils are present at the epithelial-connective tissue junction. This structure probably corresponds to a complex system of cytoplasmic processes of the basal epithelial cells (SCHENK and WERSALL, 1975; KAWABE, MACCALLUM and LILlIE, 1985); it also seems a device for the tight adherence of the epithelium, with the aid of the basal lamina, to the underlying connective tissue fibers, and for mechanical support of the epithelium.

The present study shows that each filiform papilla in the adult dog tongue contains 8-12 connective tissue papillae. In the newborn dog, however, each filiform papilla contains a connective tissue papilla in a horseshoe shape (KoBAyASHI, MiYata and InO, 1987). This suggests that the shapes and numbers of the connective tissue papillae in each filiform papilla change with age.

\section{Collagen fibrillar networks of the small intestine}

The present study has clarified the three-dimensional architecture of the collagen fibrillar networks lining the epithelium of the small intestine.

The sizes and frequencies of the pores in the collagen fibrillar network of the villi correspond neatly to those reported in the basal lamina at the same site (LOW and MCCLUGAGE, 1984; KOMURO, 1985; TAKAHASHIIwANAGA and FujiTA, 1985; MCClugage, Low and ZIMNY, 1986). The collagen fibrillar meshwork around larger pores is denser than that around the smaller ones, suggesting that free cells push away the collagen fibrils to pass through the collagen fibrillar network. There are occasional observations of smaller pores covered with several collagen fibrils. These findings suggest that the pores in the collagen fibrillar networks of the villi are formed by the cells that pass across the network and then repaired over a certain period after the passage of the cells.

The felt-like collagen fibrillar networks surrounding the intestinal glands reported here are consistent with those demonstrated by SEM of tissues treated either with a $2 \%$ aqueous solution of Tween 20 or a $0.5 \%$ EDTA phosphate-buffered solution ( $\mathrm{pH} 7.3$ ) (USHIKI, ISHII and IDE, 1986).

\section{Prospects of collagen frameworks for tissue culture}

The present study has demonstrated that the arrangements of collagen fibrils show patterns specific to individual organs and tissues. As has been partly discussed already, the collagen fibrillar framework of each tissue probably play an important role in maintaining the microenvironment suitable for cells that lodge in the framework.

It is well known that the in vitro growth capacity of cells in conventional tissue culture dishes is limited. EHRMANN and GEY (1956) pointed out that collagen gel can provide a three-dimensional environment for cultured cells. It has been reported that mammary cells embedded within a three-dimensional collagen gel matrix grow better than those cultured on plastic dishes (YANG et al., 1979, 1980; YANG and NANDI, 1983). In this connection, it seems reasonable to consider that the collagen framework produced by the present cell-maceration method may be a useful "biomatrix" (ENAT et al., 1984) for cell culture. 


\section{REFERENCES}

Casella, C.: Tensile force in total striated muscle, isolated fibre and sarcolemma. Acta Physiol. Scand. 21: 380-401 (1950).

Caulfield, J. B. and T. K. Borg: The collagen network of the heart. Lab. Invest. 40: 364-372 (1979).

Clara, M.: Über das argyrophile Gewebe ("Gitterfasern") in der menschlichen Bauchspeicheldrüse. Z. Mikrosk.Anat. Forsch. 39: 231-242 (1936).

Dolber, P. C. and M. S. SPACH: Thin collagenous septa in cardiac muscle. Anat. Rec. 218: 45-55 (1987).

Ehrmann, R. L. and G. O. GEY: The growth of cells on a transparent gel of reconstituted rat-tail collagen. J. Cancer Inst. 16: 1375-1403 (1956).

Enat, R., D. M. Jefferson, N. Ruiz-Opazo, Z. Gat MaITAN, L. A. LeinwaNd and L. M. ReID: Hepatocyte proliferation in vitro: Its dependence on the use of serum-free hormonally defined medium and substrata of extracellular matrix. Proc. Nat. Acad. Sci. USA 81: 1411-1415 (1984).

FawCETT, Don W.: A textbook of histology. W. B. Saunders, Philadelphia, 1986.

Highison, G. L. and F. N. Low: Microdissection by untrasonication after prolonged $\mathrm{OsO}_{4}$ fixation: a technique for scanning electron microscopy. J. Submicrosc. Cytol. 14: 161-170 (1982).

HolmgRen, E.: Über die Trophospongien der quergestreiften Muskelfasern, nebst Bemerkungen über den allgemeinen Bau dieser Fasern. Arch. Mikrosk. Anat. 71: 165-247 (1907).

Horstmann, E.: Über den Papillarkörper der menschlichen Haut und seine regionalen Unterschiede. Acta Anat. 14: 23-42 (1952).

- : Morphologie und Morphogenese des Papillarkörpers der Schleimhäute in der Mundhöle des Menschen. Z. Zellforsch. 39: 479-514 (1954).

-: Die Haut. In: (ed. by) W. von MöLlENDORFF and W. BARGMANN: Handbuch der mikroskopischen Anatomie des Menschen. III/1. Springer, BerlinGöttingen-Heidelberg, 1957 (p. 1-276).

Hull, M. T. and K. A. W ARFEL: Age related changes in the cutaneous basal lamina: Scanning electron microscope study. J. Invest. Dermatol. 81: 378-380 (1983).

KARRING, G. F.: Mitotic activity in the oral epithelium. J. Periodont. Res. Suppl. 13: 1-47 (1973).

KawaBe, T. T., D. K. MacCallum and J. H. Lillie: Variation in basement membrane topography in human thick skin. Anat. Rec. 211: 142-148 (1985).

Klein-Szanto, A. J. P. and H. E. Schroeder: Architecture and density of the connective tissue papillae of the human oral mucosa. J. Anat. 123: 93-109 (1977).

KoBAYASHI, K., K. MiYATA and T. IINo: Three-dimensional structure of the connective tissue papillae of the tongue in newborn dogs. Arch. Histol. Jap. 50: 347-357 (1987).
Komuro, T.: Fenestrations of the basal lamina of intestinal villi of the rat. Scanning and transmission electron microscopy. Cell Tiss. Res. 239: 183-188 (1985).

LAIDLAW, G. F.: Silver staining of the endoneurial fibers of the cerebrospinal nerves. Amer. J. Pathol. 6: 435-444 (1930).

Low, F. N. and S. G. MCClugage: Microdissection by ultrasonication: scanning electron microscopy of the epithelial basal lamina of the alimentary canal in the rat. Amer. J. Anat. 169: 137-147 (1984).

MCClugage, S. G., F. N. Low and M. L. ZimnY: Porosity of the basement membrane overlying Peyer's patches in rats and monkeys. Gastroenterology 91: 1128-1133 (1986).

Misumi, Y. and T. AKIYoshi : Scanning electron microscopic structure of the finger print as related to the dermal surface. Anat. Rec. 208: 49-55 (1984).

MiYoshi, M. and K. SHINGU : Scanning electron microscope studies of lymphatic tissues with special reference to the structure of the reticulum. Scanning Electron Microscopy 1984/I: 267-272 (1984).

MURAKAMI, T.: A revised tannin-osmium method for noncoated scanning electron microscope specimens. Arch. Histol. Jap. 36: 189-193 (1974).

NAGEL, A.: Die mechanischen Eigenschaften von Perimysium internum und Sarkolemm bei der quergestreiften Muskelfasern. Z. Zellforsch. 21: 377-386 (1934).

- : Die mechanischen Eigenschaften der Kapillarwand und ihre Bezeihungen zum Bindegewebslager. $Z$. Zellforsch. 22: 694-706 (1935).

NAGEOTTE, J.: Sheaths of the peripheral nerves. Nerve degeneration and regeneration. In: (ed. by) W. PEN. FIELD: Cytology and cellular pathology of the nervous system. Hoeber, New York, 1932 (p. 189-239).

OHTANI, O.: Three-dimensional organization of the connective tissue fibers of the human pancreas. A scanning electron microscopic study of $\mathrm{NaOH}$ treated tissues. Arch. Histol. Jap. 50: 557-566 (1987).

Perlman, E. S., K. T. Weber, J. S. JaniCki, G. G. Pietra and A. P. Fishman: Muscle fiber orientation and connective tissue content in the hypertrophied human heart. Lab. Invest. 46: 158-164 (1982).

Petersen, H.: Histologie und mikroskopische Anatomie. J. F. Bergmann, München-Wiesbaden, 1922.

PlenK, H.: Über argyrophile Fasern (Gitterfasern) und ihre Bildungszellen. Ergebn. Anat. Entw.-Gesch. 27: 302-412 (1927).

- : Die Schwannsche Scheide der markhaltigen Nervenfasern. Z. Mikrosk.-Anat. Forsch. 36: 191-214 (1934).

Robinson, T. F., L. COHEN-Gould and S. M. FACTOR : Skeletal framework of mammalian heart muscle. Arrangement of inter- and pericellular connective tissue structures. Lab. Invest. 49: 482-498 (1983).

SCHENK, P. and J. WERSALL: Die Ultrastruktur der Papillae filiformes der menschlichen Zunge. Arch. Dermatol. Forsch. 252: 91-109 (1975). 
SCHMALBRUCH, H.: The sarcolemma of skeletal muscle fibers as demonstrated by a replica technique. Cell Tiss. Res. 150: 377-387 (1974).

: Skeletal muscle. In: (ed. by) A. OKSCHE and L. VOLLRATH: Handbook of microscopic anatomy, II/6. Springer, Berlin-Heidelberg-New York-Tokyo, 1985.

Stolov, W. C. and T. G. WeILEPP, Jr.: Passive lengthtension relationship of intact muscle, epimysium, and tendon in normal and denervated gastrocnemius of the rat. Arch. Phys. Med. 47: 612-620 (1966).

Takahashi-Iwanaga, H. and T. Fujita: Lamina propria of intestinal mucosa as a typical reticular tissue. A scanning electron microscopic study of the rat jejunum. Cell Tiss. Res. 242: 57-66 (1985).

UsHIKI, T. and C. IDE: Three-dimensional architecture of the endoneurium with special reference to the collagen fibril arrangement in relation to nerve fibers. Arch. Histol. Jap. 49: 553-563 (1986).

UshiKI, T., T. ISHII and C. IDE: Comparison between light and scanning electron microscopic images of reticular fibers (In Japanese). Biomed. SEM 15: 63-66 (1986).

YANG, J. and S. NANDI: Growth of cultured cells using collagen as substrate. Int. Rev. Cytol. 81: 249-286 (1983).
YANG, J., J.RICHARDS, P. BOWMAN, R. GUZMAN, J. Enami, K. McCoRmick, S. Hamamoto, D. Pitelka and S. NANDI: Sustained growth and three-dimensional organization of primary mammary tumor epithelial cells embedded in collagen gels. Proc. Nat. Acad. Sci. USA 76: 3401-3405 (1979).

YANG, J., J. RichaRdS, R. GUZmanN, W. ImAGaWA and S. NANDI: Sustained growth in primary culture of normal mammary epithelial cells embedded in collagen gels. Proc. Nat. Acad. Sci. USA 77: 2088-2092 (1980).

Dr. O. OHTANi

Department of Anatomy

Okayama University School of Medicine Shikata-cho, Okayama

700 Japan

大谷修

700 岡山市鹿田町 2-5-1

岡山大学医学部

第二解剖学教室 